\title{
Nematicidal Effect of Biological Control Agents and Other Chemical Compounds on Meloidogyne incognita Infesting Tomato Plants
}

\author{
A. S. A. Saad, M. A. Massoud ${ }^{1}$ Hala S. Ibrahim ${ }^{2}$ and M. S. H. Khalil ${ }^{3}$
}

\begin{abstract}
Greenhouse experimental studies were conducted to evaluate certain biological control agents and other chemical compounds belonging to different groups to suppress the population density of root-knot nematodes (Meloidogyne incognita) in the sandy soil on tomato plants cv. Super strain B.

The biological control agents were the antagonistic bacterium Pseudomonas flouroscence, antagonistic fungus Trichoderma harazianum and their mixture. Meanwhile, the chemical compounds included cadusafos, fosthiazate, carbofuran and oxamyl, as well as the biopesticide abamectin.

The data revealed that carbofuran and $P$. flouroscence proved to be the most effective treatments suppressing the final population of root-knot nematodes (Meloidogyne incognita). Both carbofuran and $P$. flouroscence showed the same effect as the mean reduction of population density reached $92.7 \%$, followed by the mixture of $T$. harazianum and $P$. flouroscence $(88.9 \%)$, then $T$. harazianum alone which achieved a reduction of $88.1 \%$. Fosthiazate was the least effective treatment on population density giving a reduction of $53.7 \%$.
\end{abstract}

Cadusafos gave the highest reduction percentage $(55.3 \%)$ on galls $/ 5 \mathrm{~g}$ roots, followed by abamectin, oxamyl and fosthiazate which recorded 54, 53.9 and 51.1\% reduction, respectively. Meanwhile, $T$. harazianum recorded the least reduction in galls $(\mathbf{1 1 . 5 \%})$.

Abamectin gave the highest reduction $(\mathbf{7 7 . 2} \%)$ of root-egg masses/5g roots followed by fosthiazate, oxamyl and the mixture of $T$. harazianum and $P$. flouroscence $(63.9 \%, 60.9 \%$ and $60.4 \%$ reduction), respectively.

All the evaluated treatments proved to be effective in enhancing the plant growth of tomatoes and showed indirect effect on the length and weight of root and shoot systems. Abamectin was the superior treatment in increasing the root system length by $44.2 \%$. on the other hand, the mixture of $T$. harazianum and $P$. flouroscence decreased the root system length by $4.1 \%$.

$P$. flouroscence was the most effective treatment achieving an increase of $88.7 \%$ in root system fresh weight, followed by abamectin and cadusafos which gave $87.4 \%$ and $81.0 \%$ increasing. However, T. harazianum showed the least increase in root system fresh weight (20.9\%).

\footnotetext{
${ }^{1}$ Faculty of Agriculture Saba pasha, Alexandria University.

${ }^{2}$ Central Agricultural Pesticides Laboratory, A.R.C., Dokki-Giza.

${ }^{3}$ Central Agricultural Pesticides Laboratory, A.R.C.,

El-sabaheya, Alexandria

Received August 5, 2010, Accepted September 1, 2010
}

Also, $P$. flouroscence gave the highest increase percentage of the shoot system length followed by abamectin and carbofuran.

In respect to the shoot system weight, abamectin gave the highest increase over all the tested treatments $(94.4 \%)$, followed by fosthiazate and $P$. flouroscence which recorded increase of $90.9 \%$ and $89.4 \%$, respectively. Vice versa, $T$. harazianum recorded the least increase in both shoot system length and weight giving increase of $58.7 \%$ and $72.8 \%$, respectively, compared with the untreated check.

\section{INTRODUCTION}

Tomato (Lycopersicon esculentum, Mill) represents an important vegetable crop in Egypt. Tomato fruits are considered to be one of the important sources for carbohydrates, protein, fats, fiber, minerals and vitamins (Howeedy et al., 2003).

Meloidogyne, the root-knot nematodes, contains more than 70 described species, four of them $(M$. incognita, M. arenaria, M. javanica and M. hapla) are responsible for $95 \%$ of infestations (Sasser et al., 1983). Root-knot nematodes (Meloidogyne spp.) cause high levels of economic loss in a multitude of agricultural crops worldwide. They are capable of severely damaging a wide range of crops, in particular vegetables, causing dramatic yield losses mainly in tropical and sub-tropical agriculture (Sikora and Fernandez, 2005).

Among the root-knot nematodes, Meloidogyne javanica, M. incognita, M. arenaria, and M. hapla are of major agronomic importance, being responsible for at least $90 \%$ of all damage caused by these nematodes (Castagnone-Sereno, 2002). These nematodes can be particular menace in third world countries where most peasant farmers are unaware of these "hidden enemies" and do not take steps to manage them.

A number of methods for the management of the root-knot nematode such as chemical control, organic amendments, resistant varieties, soil solarization and biological control have been tried with different levels of successes for the protection of tomato plants (Randhawa et al., 2001\& Sakhuja and Jain, 2001). Biopesticides and microbial pathogens are being a new 
line which developed and improved to be an important tool in the IPM programs. A wide variety of soil organisms are known as predators or parasites of plantparasitic nematodes (Coleman and Crossley, 1996; Dindal, 1990 and Stirling, 1991). Several attempts have been made to use antagonistic fungi to control root-knot nematodes (Sharon et al., 2001).

The root-knot nematodes, (Meloidogyne incognita) are considered to be the most difficult crop-pests to be controlled and due to the adverse effects of pesticides on the environment and human health, this investigation aimed to: (a) study the positive performance of certain biological control agents and other chemical compounds belonging to different chemical groups against rootknot nematodes, (Meloidogyne incognita). (b) determine the effect of microorganisms and biopesticide as safety and alternative control methods. (c) study the impact of the evaluated treatments on plant growth parameters.

\section{MATERIALS AND METHODS}

\section{Biological control agents and chemicals compounds:}

\section{1) Biological control agents:}

\section{A) Antagonistic fungus.}

The fungus (Trichoderma harazianum) was obtained from the biofertilizer center, Ain Shams University. The suspension was counted by a microscope. Each ml contains $1 \times 10^{5}$ spores. Every plant received $50 \mathrm{ml}$ of the suspension $\left(5 \times 10^{6}\right.$ spore / plant $)$.

\section{B) Antagonistic bacterium.}

The bacterium (Pseudomonas flouroscence) was obtained from the biofertilizer center, Ain Shams University. The suspension was counted through the spectrophotometer at the wave length of $550 \mathrm{~nm}$. Measuring the optical densities on the standard curve showed that every $\mathrm{ml}$ contains $3.8 \times 10^{4}$ CFU. Every plant received $50 \mathrm{ml}$ of the suspension $\left(1.9 \times 10^{6} \mathrm{CFU} /\right.$ plant).

\section{C) Antagonistic fungus and bacterium mixture.}

A mixture of the antagonistic fungus and the antagonistic bacterium was employed by mixing the half dose of both $\left\{\left(2.5 \times 10^{6}\right.\right.$ spore $\left.)+\left(95 \times 10^{4} \mathrm{CFU}\right)\right\} /$ plant.

\section{D) Biopesticide agent:}

Vertemic $^{\circledR} \quad 1.8 \quad \% \quad$ EC $\quad$ (Abamectin), $(10 E, 14 E, 16 E, 22 Z)-$ $\left(1 R, 4 S, 5^{\prime} S, 6 S, 6 ' R, 8 R, 12 S, 13 S, 20 R, 21 R, 24 S\right)-\quad 6^{\prime}-\quad[(S)-$ sec- butyl] -21,24-dihydroxy-5',11,13,22-tetramethyl-2oxo-3,7,19-trioxatetracyclo[15.6.1.1 $\left.1^{4,8} \cdot 0^{20,24}\right]$ pentacosa$10,14,16,22-\quad$ tetraene-6-spiro-2'-(5',6'-dihydro-2' $H$ pyran)-12-yl 2,6-dideoxy-4- $O$-,6-dideoxy-3- $O$-methyl$\alpha$-L-arabino- hexopyranosyl)-3- $O$-methyl- $\alpha-\quad$ L- arabino-hexopyranoside

$(10 E, 14 E, 16 E, 22 Z)-$

(i)

$8 R, 12 S, 13 S, 20 R, 21 R, 24 S)-21,24-$

mixture with $\left(1 R, 4 S, 5^{\prime} S, 6 S, 66^{\prime} R\right.$, dihydroxy-6'isopropyl- $\quad 5$ ',11,13,22-tetramethyl-2-oxo-3,7,19trioxatetracyclo[15.6.1.1 $\left.1^{4,8} \cdot 0^{20,24}\right] \quad$ pentacosa$10,14,16,22$ - tetraene-6- spiro-2'-(5',6'-dihydro-2' $H$ pyran)-12-yl 2,6- dideoxy-4-O-(2,6- dideoxy-3-5 methyl- $\alpha$-L-arabino- hexopyranosyl)-3-O-methyl- $\alpha-\mathrm{L}-$ arabino-hexopyranoside (ii) $(4: 1)$.

\section{2) Chemical compounds:}

\section{A) Organophosphorus compounds.}

1) Nemathorin ${ }^{\circledR} 10 \% \mathrm{G}$ (fosthiazate), [RS-S-sec-butyl $O$-ethyl 2-oxo-1,3-thiazolidin-3-yl phosphonothioate; $(R S)-3-[\mathrm{sec}-$

butylthio(ethoxy)phosphinoyl]-1,3-thiazolidin-2one].

2) Rugby ${ }^{\circledR} 10 \% \mathrm{G}$ (cadusafos), $[S, S$-di-sec-butyl $O$ ethyl phosphorodithioate].

B) Carbamates compounds.

1) $\operatorname{Cartan}^{\circledR} 10 \% \quad \mathrm{G}$ (carbofuran),[2,3-dihydro-2,2dimethylbenzofuran-7-yl methylcarbamate].

2) Vydate ${ }^{\circledR} 10 \% \quad \mathrm{G} \quad$ (oxamyl), [ $N, \quad N$-dimethyl-2methylcarbamoyloxyimino-2-(methylthio) acetamide].

\section{The Greenhouse Experiment.}

Greenhouse experiment was carried out on a susceptible tomato plants cv. Super strain B to Meloidogyne incognita. Identification of the species of the root-knot nematode (Meloidogyne incognita) was done by using the perineal patterns method according to Taylor and Nelscher (1974). In the end of the experiment, second stage juveniles (J2) were extracted from $250 \mathrm{~g}$ soil using sieving and baermann plates' technique (Ayoub, 1980). The greenhouse contained eight different evaluated treatments in sandy soil beside the untreated check and each treatment was replicated ten times.

The Soil samples were monthly collected according to Barker (1985) for three months after treatment to determine the efficacy of the tested nematicides on the nematode population densities in the soil which utilized according to the recommended dose of MAC (Ministry of Agriculture). Meanwhile, the biopesticide abamectin was applied at the rate of $11.11 \mathrm{ml} / 1$. The evaluated biological control agent and chemical compounds were applied to the soil for one time.

The shoot length, shoot weight, root length, root weight, galls number / $5 \mathrm{~g}$ roots, egg masses $/ 5 \mathrm{~g}$ root system and number of juveniles / $250 \mathrm{~g}$ soil were determined. The roots were stained for 15 minutes in an aqueous solution of phloxine B stain ( $0.15 \mathrm{~g} / 1$ water), 
then they have been washed with running tap water to remove residual stain and to emphasize nematode egg masses (Holbrook et al., 1983).

The reduction percentage of infection was calculated after one, two and three months from treatment according to Hende nd Tilton' 'n 15 ) as follows:

Reduction $\left.\%=\left\{1-\frac{\mathrm{a}}{\mathrm{b}} \times \frac{\mathrm{c}}{\mathrm{d}}\right)\right\} \times 100$ Where:

$\mathrm{a}=$ Population density in treatment after application

$\mathrm{b}=$ Population density in treatment before application

$\mathrm{c}=$ Population density in check untreated (control) before application

$\mathrm{d}=$ Population density in check untreated after application

\section{Fertilization and irrigation}

Fertilization was carried out through the drip irrigation lines (fertigation). On the other side, the irrigation was carried out through the drip irrigation lines two times / day.

\section{Statistical analysis}

The data were subjected to the analysis of variance test (ANOVA) as complete randomized design for greenhouse experiment. The least significant difference (LSD) at the $5 \%$ level of probability was determined using a Costat program and Multiple Range (Duncan, 1955).

\section{RESULTS AND DISCUSSION}

The influence of biological control agents and other chemical compounds on the nematode population:

The data presented in Table (1) indicated the reduction percentage of the evaluated biological control agents and other chemical compounds on the numbers of second Juvenile stage $\left(\mathrm{J}_{2}\right)$ at $250 \mathrm{~g}$ sandy soil. The efficacy was monthly recorded for three successive months after treatment.
It is obvious that the efficacy of the biological control agents and other chemical compounds was varied. It was noticed that most of the treatments increased the reduction percentage in the second month. While the results showed decreasing in the efficacy of carbofuran and cadusafos. On the other hand, the biological performance of carbofuran, cadusafos, $T$. harazianum and $P$. flouroscence were increased at the third month. Moreover, the effectiveness of fosthiazate, oxamyl, abamectin and the mixture of $T$. harazianum plus $P$. flouroscence were decreased in the third month.

The results of the effectiveness of the tested compounds against the root-knot nematode populations revealed that both carbofuran and $P$. flouroscence gave $92.7 \%$ reduction, followed by the mixture of $T$. harazianum and $P$. flouroscence and $T$. harazianum alone which recorded reductions of $88.9 \%$ and $88.1 \%$, respectively.

These results are in agreement with those obtained by Sharma and Sharma (1995); Enokpa et al. (1996); Indira et al. (2001) and Kumari and Sivakumar (2005) who confirmed that carbofuran gave reduction of galls and nematode population of Meloidogyne incognita.

Also, Rich et al. (1994) and Lawrence and McLean (1995) reported that fosthiazate reduced the nematodes galls and Meloidogyne incognita numbers. Ibrahim et al. (2010) found that Pseudomonas fluorescens was superior treatment in reducing of nematodes population by $79.4 \%$.

The possible action of the antagonistic bacterium Pseudomonas fluorescens strain was due to the capability of altering root exudates which could alter nematode behavior and suppress nematode population in root system (Oostendrop and Sikora, 1989). Also, the antibiotic production and competition with pathogens for essential nutrients such as iron, and more indirectly through plant growth promotion (Gamliel and Katan, 1993 and Siddiqui and Mahmood, 1998). Moreover, the production of hydrogen cyanide $(\mathrm{HCN})$ as a secondary metabolite (Imran et al., 2006).

Table 1. The reduction percentage of the nematode population due to the application of biological control agents and other chemical compounds in tomato plants

\begin{tabular}{lccc}
\hline \multirow{2}{*}{ Treatments } & \multicolumn{2}{c}{ The reduction percent age of nematodes at three intervals after application } \\
\cline { 2 - 4 } Abamectin & First month & Second month & Third month \\
\hline Carbofuran & 86.5 & 86.6 & 74.0 \\
\hline Cadusafos & 87.6 & 80.8 & 92.7 \\
\hline Fosthiazate & 72.0 & 71.6 & 83.1 \\
\hline Oxamyl & 59.5 & 87.2 & 53.7 \\
\hline Pseudomonas flouroscence & 79.3 & 91.9 & 56.4 \\
\hline Trichoderma harazianum & 81.1 & 84.6 & 92.7 \\
\hline
\end{tabular}


The influence of biological agents and other chemical compounds on the rate of counted root galls and egg masses:

Data in Table (2) indicated that all treatments were effective against root galls and egg masses / $5 \mathrm{~g}$ roots compared with the untreated check. Cadusafos was the superior treatment which recorded $55.3 \%$ reduction of root galls followed by abamectin, oxamyl and fosthiazate which recorded 54\%, 53.9\%, and 51.1\% reduction, respectively.These results are in agreement with those of Sharma et al. (2008) who found that Pseudomonas fluorescens decreased nematode penetration and galling by $54 \%$ and $70 \%$, successively. Also, Bhat et al. (2005); Pathan et al. (2005) and Singh (2006) indicated that carbofuran was the most effective treatment in reducing the larval population and the gall number. Kalaiarasan et al. (2006) exhibited that chitinolytic biological control agents Pseudomonas fluorescens and Trichoderma viride decreased the galls number / plant.

Moreover, in the case of egg masses, abamectin was the effective treatment that gave $77.2 \%$ reduction, followed by fosthiazate, oxamyl and the mixture of $P$. flouroscence plus T. harazianum achieving $63.9 \%$, $60.9 \%$ and $60.4 \%$ reduction, in respect. T. harazianum showed the least reduction in both root galls and egg masses / $5 \mathrm{~g}$ roots which gave $11.5 \%$ and $38.3 \%$, consecutively.
The finding results are similar to those reported by Khalil (2009) and Ibrahim et al. (2010) who found that abamectin, oxamyl and fosthiazate were the most effective treatments against egg masses of the root-knot nematode on tomato plants in clay soil cultivated under greenhouse conditions.

Also, Sharma et al. (1997) and Pathan et al. (2005) found that $P$. lilacinus along with furadan significantly reduced the number of galls / plant, egg-masses / root and eggs / egg-mass, the number of larvae / $200 \mathrm{~g}$ soil and females / $5 \mathrm{~g}$ root.

The action of the antagonistic fungus Trichoderma spp in multitude investigations, were interpreted as a producer of volatile and non volatile toxic metabolites such as arzianic acid, alamethicins, tricholin, peptaibols antibiotics, viridian and others (Vey et al., 2001). Tikhonov et al. (2002) found that the chitinolytic system of Trichoderma comprises many enzymes such proteases that together with chitinases are able to degrade nematode egg-shell. Also, the competition for nutrients specially iron which essential for viability decreased the available nutrients for the nematode (Eisendle et al., 2004).

Moreover, there are a general agreement that the toxic action of organophosphate and carbamate pesticides on nematodes and insects is due to their ability to inhibit acetylcholinesterase (AChE) in various parts of the nervous system thereby disrupt nervous transmission at that location (Corbett et al., 1984).

Table 2. The influence of biological control agents and other chemical compounds on the root galls and egg masses in tomato plants

\begin{tabular}{lcccc}
\multirow{2}{*}{ Treatments } & \multicolumn{3}{c}{ NO. / 5g roots } \\
\cline { 2 - 5 } & \multicolumn{2}{c}{ Galls } & \multicolumn{2}{c}{ Egg masses } \\
\cline { 2 - 5 } & $\begin{array}{c}\text { Average } \\
(\mathbf{N O})\end{array}$ & $\begin{array}{c}\text { Reduction } \\
(\boldsymbol{\%})\end{array}$ & $\begin{array}{c}\text { Average } \\
(\text { NO.) }\end{array}$ & $\begin{array}{c}\text { Reduction } \\
(\%)\end{array}$ \\
\hline Abamectin & $478.3 \mathrm{bc} *$ & 54.0 & $338.3 \mathrm{ef}$ & 77.2 \\
\hline Carbofuran & $611.7 \mathrm{~b}$ & 41.2 & $710.0 \mathrm{bc}$ & 52.2 \\
\hline Cadusafos & $465.0 \mathrm{bc}$ & 55.3 & $860.0 \mathrm{~b}$ & 42.1 \\
\hline Fosthiazate & $508.3 \mathrm{bc}$ & 51.1 & $536.7 \mathrm{cdef}$ & 63.9 \\
\hline Oxamyl & $480.0 \mathrm{bc}$ & 53.9 & $580.0 \mathrm{cdef}$ & 60.9 \\
\hline Pseudomonas flouroscence & $633.3 \mathrm{~b}$ & 39.1 & $613.3 \mathrm{~cd}$ & 58.7 \\
\hline Trichoderma harazianum & $920.0 \mathrm{a}$ & 11.5 & $916.7 \mathrm{~b}$ & 38.3 \\
\hline P.flouroscence + T. harazianum & $631.7 \mathrm{~b}$ & 39.3 & $588.3 \mathrm{cde}$ & 60.4 \\
\hline Untreated check & $1040.0 \mathrm{a}$ & -- & $1485.0 \mathrm{a}$ & -- \\
\hline
\end{tabular}

*Within a column, values followed by different letter ( $\mathrm{s}$ ) are significantly different using LSD at P = 0.05 


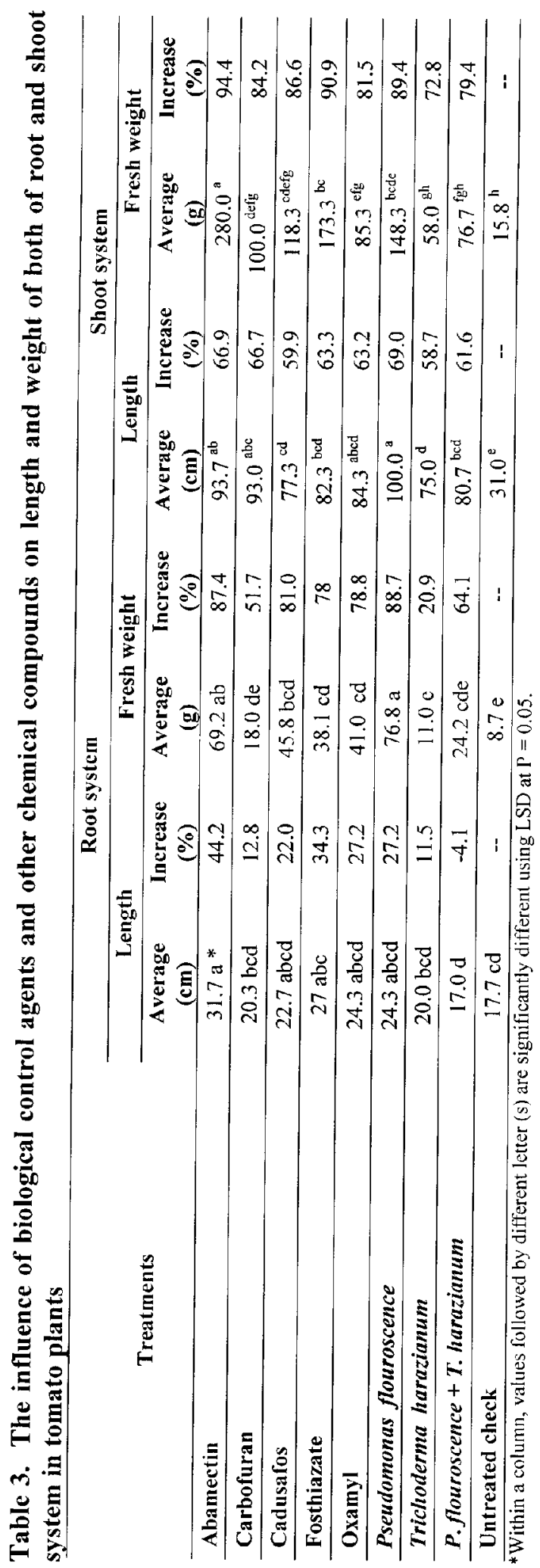


Indirect effect of studied biological agents and other chemical compounds on the length and weight of the root system:

The results in Table (3) showed the side effect of the different evaluated treatments on length and weight of the root system. It is clear that abamectin was the most effective treatment on the root system length which gave $44.2 \%$ increase, followed by fosthiazate, oxamyl and $P$. flouroscence that recorded 34.3, 27.2 and $27.2 \%$ increase, in sequence. While, the least effective treatment was the mixture of $P$. flouroscence plus $T$. harazianum giving a reduction of $4.1 \%$. Therefore, it could be said that the mixture of $P$. flouroscence $+T$. harazianum was the only treatment that decreased the root length compared with the other running treatments.

Pseudomonas flouroscence alone was the superior treatment in increasing the fresh weight of root system by $88.7 \%$, followed by abamectin, cadusafos and oxamyl achieving $87.4,81.0$ and $78.8 \%$ increase, respectively, while, $T$. harazianum exhibited the least root system weight $(11 \mathrm{~g})$ and recorded an increase of $20.9 \%$.

Indirect effect of tested biological agents and other chemical compounds on the length and weight of the tomatoes shoot system.

Data shown in Table (3) indicated the effect of the evaluated treatments on the length and weight of the shoot system in the sandy soil. $P$. flouroscence exhibited the highest increase in shoot system length (69.0 \%), followed by abamectin and carbofuran achieving increase of 66.9 and $66.7 \%$, consecutively.

Moreover, abamectin recorded the highest significant increase in shoot system weight which estimated by $94.4 \%$, followed by fosthiazate and $P$. flouroscence that gave $90.9 \%$ and $89.4 \%$, respectively. The fungus $T$. harazianum showed the least increase in both length and weigh of the shoot system performing $58.7 \%$ and $72.8 \%$, respectively.

These findings are in agreement with those reported by Krishnaveni and Subramanian (2004) and Shanthi and Sivakumar (2005) who indicated that the yield of those plants treated with Pseudomonas fluoroscence was increased. Also, Kavitha et al. (2007) found that Pseudomonas fluorescens, Bacillus subtilis and Trichoderma viride showed a significant increase in the plant growth parameters. Also, Ibrahim et al. (2010) found that Trichoderma harazianum, oxamyl and fosthiazate increased the length and weight of the shoot system significantly.

\section{REFERENCES}

Ayoub, S.M. (1980). Plant nematology, an agricultural training aid nema. Aid Publications populations, California, USA. pp.195.

Barker, K. R. (1985). Sampling nematode communities. pp317 in Barker, K. R.; C. C. Carte and J. N. Sasser, (eds). An advanced treatise on Meloidogyne, vol. 11,methodology. North Carolina State Univ. Graphics.

Bhat, O.K.; V. Koul; K.C. Bhagat; V.K. Koul and R. Bhan (2005). Management of root knot nematode, Meloidogyne incognita infesting tomato. Environment and Ecology, 23(2): 403-407.

Castagnone-Sereno, P. (2002). Genetic variability in parthenogenetic root-knot nematodes,Meloidogyne spp., and their ability to overcome plant resistance genes. Nematologica, 4: 605-608.

Coleman, D.C. and D.A. Crossley (1996). Fundamentals of Soil Ecology. Academic Press, San Diego, CA, USA.

Corbett, J. R.; K. Wright and A. C. Baillie (1984). The biochemical mode of action of pesticides. Second Edition. London, Academic Press, 382 p.

Dindal, D.L. (1990). Soil Biology Guide. John Wiley and Sons, NewYork.

Duncan, D.B. (1955). Multiple range and multiple $F$ tests. Biometrics, 11: 1-4.

Eisendle, M.; H.Oberegger; R. Buttinger; P. Illmer and H. Haas (2004).Biosynthesis and uptake of siderophores is controlled by the PacC mediated ambient-pH regulatory system in Aspergillus nidulans. Euk Cell, 3: 561-563.

Enokpa, E.N.; I.A. Okwujiako and B.E. Madunagu (1996). Control of root-knot nematodes in tomato with Furadan. Global J. Pure Applied Scie., 2(2): 131-136.

Gamliel, A. and J. Katan (1993). Suppression of major and minor pathogens by fluorescent pseudomonads in solarized and non solarized soil. Phytopathology, 83: 6875.

Henderson, C.F. and E.W. Tilton (1955). Tests with acaricides against the brown wheat mite. J. Econ. Entomol., 48:157-160.

Holbrook, C.C.; D. A. Knauft and D.W. Dikson (1983). A techiqne for screening peanut for resistance to Meloidogyne arenaria. Plant Dis., 57: 957-958.

Howeedy, A.; N. G. henna; A. Shawkey and F. Abdel-Aziz (2003). Tomato production and cultivate. Technique Bulletin No. 816 of Agricultural Research Center. pp. 84.

Ibrahim, H. S.; A. S. A. Saad; M. A. Massoud and M. S. H. Khalil (2010). Evaluation of certain agrochemical and biological agents against Meloidogyne incognita on tomatoes. Alex. Sci. Exch. J., 31(1):10-17.

Imran,A. S.; S. S. Shaukat' I. H. Sheikh and A. Khan (2006). Role of cyanide production Pseudomonas fluorescens CHA0 in the suppression of root-knot nematode, Meloidogyne javanica in tomato. World J. Microbiol. \& Biotechnol., 22: 641-650. 
Indira, V.; S. P. Tiwari; B. N. Shukla (2001). Estimation of yield losses in tomato and integrated management of root-knot nematode, Meloidogyne incognita. Indian Phytopathology, 54(4): 495-496.

Kalaiarasan, P.; P. Lakshmanan; G. Rajendran; and R. Samiyappan (2006). Chitin and chitinolytic biocontrol agents for the management of root-knot nematode, Meloidogyne arenaria in groundnut (Arachis hypogaea L.) cv. Co3. Indian J. Nematology, 6(2): 200-205.

Kavitha, J.; E.I. Jonathan and R. Umamaheswari (2007). Field application of Pseudomonas fluorescens, Bacillus subtilis and Trichoderma viride for the control of Meloidogyne incognita (Kofoid and White) Chitwood on sugarbeet. J.Biological Control. Society for Biocontrol Advancement, Bangalore, India, 21 (2): 211-215.

Khalil, M. S. H. (2009). Influence of nematicides and certain natural products on infestation of nematodes attacking tomato plants (Lycopersicon esculentum, Mill). M. Sc. Thesis, Faculty of Agric., Alexandria Univ., Egypt.

Krishnaveni, M. and S. Subramanian (2004). Evaluation of biocontrol agents for the management of Meloidogyne incognita on cucumber (Cucumis sativus L). Current Nematology, 15(1/2): 33-37.

Kumari, N.S. and C.V. Sivakumar (2005). Integrated management of root-knot nematode, Meloidogyne incognita infestation in tomato and grapevine. Com. Agric Appl. Biol. Sci., 70(4): 909-914.

Lawrence, G.W. and K.S. McLean (1995). Efficacy of fosthiazate on root-knot nematode on cantaloupe. Fungicide and Nematicide Tests, 50: 186 (Abstract).

Oostendrop, M. and R.A. Sikora (1989). Utilization of antagonistic rhizobacteria as a seed treatment for the biological control of Heterodera schachtii in sugarbeet. Revue de Nematology, 12: 77-83.

Pathan, M.A.; S.H. Soomro; M.M. Jiskani; K.H. Wagan and J.A. Memon (2005). Effect of Paecilomyces lilacinus and furadan on plant growth, root nodulation and reproduction of Meloidogyne incognita in tomato. Pakistan J. Nematology, 23(1): 67-71.

Randhawa, N.; P.K. Sakhuja and I. Singh (2001). Management of root-knot nematode Meloidogyne incognita in tomato with organic amendments. Plant Dis. Res., 16: 274-276.

Rich, J.R.; R.A. Dunn; W.D. Thomas; J.W. Breman and R.S. Tervola (1994). Evaluation of fosthiazate for management of Meloidogyne javanica in Florida flue cured tobacco. J. Nematology, 26(4 Supp.): 701-704.

Sakhuja, P.K. and R.K. Jain (2001). Nematode diseases of vegetable crops and the management. In: Diseases of Fruits and Vegetables and their Management. Thind, T.S. (Ed.), Kalyani Pub., Ludhiana, India

Sasser, J. N.; J. D. Eisenback; C. C. Carter and A. C. Triantaphyllou (1983). The International Meloidogyne project its goals and accomplishments. Ann. Rev Phytopathol., 21: 271-288.

Shanthi, A. and M. Sivakumar (2005). Ecofriendly approaches for the management of root-knot nematode, Meloidogyne incognita in tomato. J. Plant Protec. Environ., 2(2): 154157.

Sharma, G.L.; and M.K. Sharma (1995). Management of rootknot nematodes (Meloidogyne incognita and $M$. javanica) in tomato by bare root dip treatment. Indian J. Nematology, 25 (2): 174-176.

Sharma, R.; S.S. Dhaliwal and P.S. Chandurkar (1997). Evaluation of chemical and botanical nematicides for nematode management on brinjal. Indian J. Plant Protec., 25(1): 4-7.

Sharma, H.K.; A. Kamra; Pankaj; J. Lal and J. Kumar (2008). Effect of seed treatment with Pseudomonas fluorescens alone and in combination with soil application of carbofuran and neem seed powder against Meloidogyne incognita in okra. Pesticide Res., J. Soci. Pesticide Sci. India, 20 (1): 79-82.

Sharon, E.; M. Bar-Eyal; I. Chet; A. Herrera-Estrella; O. Kleifeld and Y. Spiegel (2001).Biological control of the root-knot nematode Meloidogyne javanica by Trichoderma harzianum. Phytopathology, 91: 687- 693.

Siddiqui, Z. A. and I. Mahmood (1998). Effect of a plant growth promoting bacterium, an AM fungus and soil types on the morphometrics and reproduction of Meloidogyne javanica on tomato. Appl. Soil Ecol., 8: 7784.

Sikora, R.A. and E. Fernandez (2005). Nematode parasites of vegetables. In: Plant-Parasitic Nematodes in Subtropical and Tropical Agriculture, Luc, M., Sikora, R.A. and J. Bridge, (Eds.), $2^{\text {nd }}$ ed. CABI Publishing, Wallingford, UK, pp. 319-392.

Singh, V.K. (2006). Management of root-knot nematode, Meloidogyne incognita infecting cauliflower. Indian J. Nematology, 36(1): 127.

.Stirling, G.R. (1991). Biological Control of Plant Parasitic Nematodes. CAB International, Wallingford, UK.

Taylor, D.P. and C. Nelscher (1974). An improved technique for preparing perineal patterns of Meloidogyne spp. Nematologica, 20: 268-269.

Tikhonov, V.E.; L.V. Lopez-Llorca; J. Salinas and H.B.Jansson (2002). Purification and characterization of chitinases from the nematophagous fungi Verticillium chlamydosporium and $V$. suchlasporium. Fung. Gen. Biol., 35: 67-78.

Vey, A.; R.E. Hoagland and T.M. Butt (2001). Toxic metabolites of fungal biocontrol agents. In: Fungi as biocontrol agents: Progress, problems and potential. Butt, T.M.; C. Jackson and N. Magan (eds), CAB International Bristol, pp 311-346. 



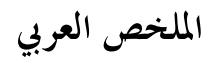

\section{التأثير النيماتودى لعو امل المكافحة الحيوية وبعض المركبات الكيماوية على نيماتودا تعقد الجذور المتطفلة على نباتات الطماطم}

$$
\text { تعبد الفتاح سيدعبدالكريم سعد، بحدى عبد الظاهر مسعود، هالة سعد إبراهيم، محمد صلاح الدين حسن خليل }
$$

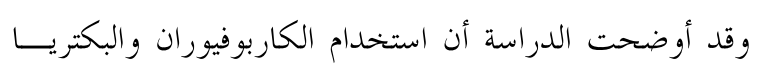

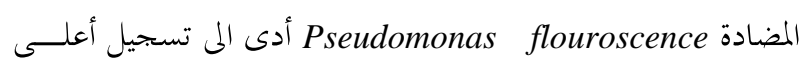

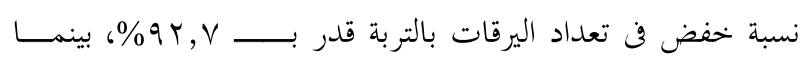

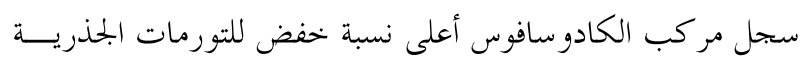

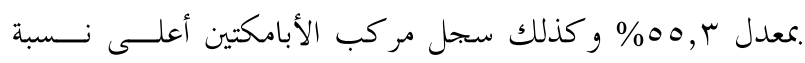

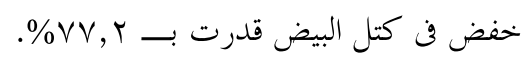
وقد بينت الدراسة أيضا أن البكتريا المضادة عseudomonas flouroscence

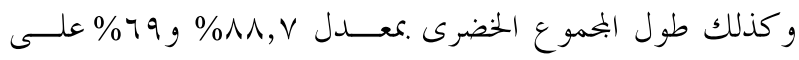

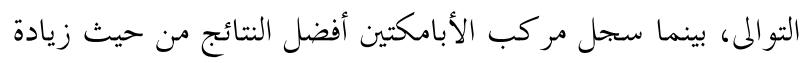

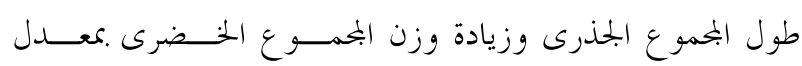

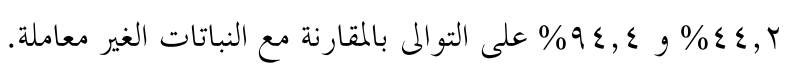
تم دراسة تأثير بعض عوامل المكافحة الحيوية وبعض المركبات

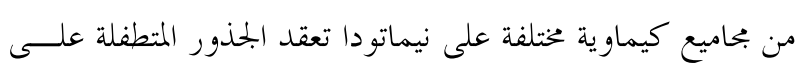

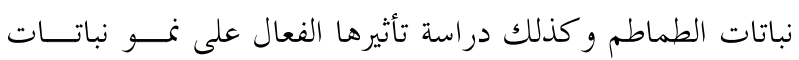
الطماطم فن التربة الرملية تحت ظروف الصوب دراس البلاستيكية.

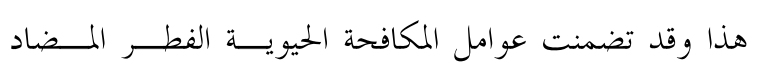

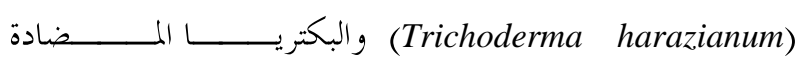

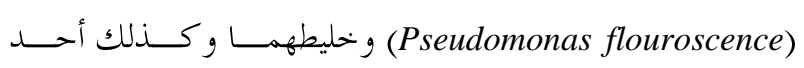
المركبات الحيوية (الأبامكتين)، بينما ضمت المركبات الكيماويسـة

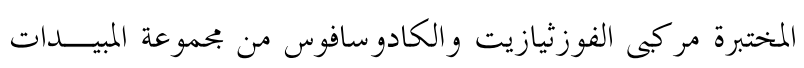

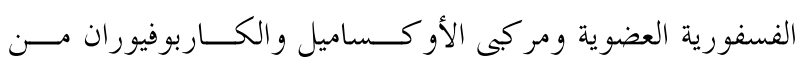
بحموعة المبيدات الكارباماتية. 